\title{
ACRL members running for ALA Council
}

The following ACRL members are either nominated or petition candidates for ALA councilor in the spring of 2009 election. ACRL members are encouraged to vote for these candidates to increase ACRL's voice in ALA affairs.

Rosie L. Albritton, director of library services, Prairie View A\&M University

J. Douglas (Doug) Archer, reference and peace studies librarian, University of Notre Dame

Mario Ascencio, visual arts liaison librarian, George Mason University

Dreanna Belden, coordinator of grants and development, University of North Texas

Karl F. Bridges, associate professor, information and instruction services, University of Vermont

John M. Budd, professor, University of Missouri

Linda Dobb, university librarian, California State University-East Bay

Aaron W. Dobbs, electronic resources and systems librarian, Shippensburg University of Pennsylvania

Charles L. Gilreath, executive associate dean, Texas A\&M University

Mario M. Gonzalez, trustee, Orangeburg Library

Patricia L. Gregory, assistant university librarian for research and assessment, Saint Louis University

Jody K. Howard, professor, University of Denver

Alys Jordan, distance and instructional services librarian, Nova Southeastern University
Alfred Kagan, African studies bibliographer, University of Illinois

Peter McDonald, dean of library services, California State UniversityFresno

Michael J. Miller, coordinator of access services, Queens College, CUNY

Susan Miller, reference librarian, Community College of Rhode Island

Leslie Monsalve-Jones, library director, Southwestern College

Nadia Nasr, university archivist and digital collections librarian, Towson University

Gail Schlachter, president, Reference Service Press

Thomas Schneiter, assistant director for the depository, Harvard University

Patricia H. (Pat) Smith, executive director, Texas Library Association

James Teliha, associate university librarian for public services, Idaho State University

Stephen Van Buren, university archivist, head of special collections, South Dakota State University

Yuhfen Diana Wu, librarian coordinator for international students, San Jose State

Diane Zabel, Louis and Virginia Benzak business librarian, Pennsylvania State University 